\title{
DIETARY COMPOSITION AND FUNCTIONAL PROPERTIES OF SELECTED WATERMELON SEEDS AVAILABLE IN BANGLADESH
}

\author{
J.A. Japu ${ }^{1}$, S. Ahmed ${ }^{2}$, M.A. Hossain ${ }^{1}$, T. Ahmed ${ }^{1}$ and M.S. Ali ${ }^{3 *}$ \\ ${ }^{1}$ Department of Applied Food Science and Nutrition \\ ${ }^{2}$ Department of Food Processing and Engineering \\ ${ }^{3}$ Department of Applied Chemistry and Chemical Technology \\ Faculty of Food Science and Technology \\ Chattogram Veterinary and Animal Sciences University, Khulshi, Chattogram, Bangladesh
}

\begin{abstract}
This study was carried out to investigate the nutritional composition and functional properties of two varieties of watermelon seeds and compare these properties between these seeds for harnessing them for consumption as food. The dried seeds of the two types of watermelon were evaluated by using a standard method for different characteristics such as nutritional, phytochemical and functional properties to perceive the potential benefits of that seed. The result of nutritional composition and phytochemical compound analysis obtained for the two varieties (Crimson red and Charleston gray) of watermelon seed indicated that both varieties of watermelon seed were rich in energy $(469.60 \pm 0.01 \mathrm{Kcal} / 100 \mathrm{~g}, \quad 408.85 \pm 0.01 \mathrm{Kcal} / 100 \mathrm{~g})$, crude fat $(36.61 \pm 0.01 \%, \quad 30.65 \pm 0.01 \%)$, crude protein $(27.21 \pm 0.01 \%$, $22.51 \pm 0.01 \%)$, fiber $(21.55 \pm 0.01,29.85 \pm 0.01 \%)$ and phytochemical compound such as crude alkaloid $(14.05 \pm 0.006 \%, 10.56 \pm 0.006 \%)$ respectively. The study result showed that, the crude fat, crude protein, energy and crude alkaloid were found to be high in the amount in the Crimson red seed than Charleston gray seed. Whereas the crude fiber was the high amount in the Charleston gray seed compared to the Crimson red seed. Functional properties may impact the behavior of food protein during processing, formulation and storage. The functional properties such as water absorption capacity, oil absorption capacity, emulsion activity, emulsion stability, foam activity, and foam stability were analysed of two varieties of watermelon seeds. The present research study revealed that both the two varieties of watermelon seed are characterized with good functional properties which indicate that the watermelon seeds can be incorporated in the formulation of food for consumption and use for industrial purposes.
\end{abstract}

\footnotetext{
* Corresponding Author: shaokat.fst@gmail.com
} 
Keyword: Watermelon seed, Dietary composition, Phytochemical compound, Functional properties

\section{INTRODUCTION}

Bangladesh has a favorable environment to cultivate different types of crops such as paddy, wheat, pea, soybean, sunflower, mustard, etc., and also several kinds of fruits such as olive, jackfruit, mango, watermelon etc. (Hoque et al., 2015). Watermelon (Citrullus lanatus) is a very common tasty and juicy fruit in Bangladesh that belongs to the family of Cucurbitaceae. It is an important crop during the hot season to meet the demand for water as it contains 90 percent of water. It also contains vitamins (A, $\mathrm{B}, \mathrm{C})$ and minerals. Watermelon is produced in different areas of Bangladesh. There are cultivated different indigenous varieties of watermelon such as sugar baby, Charleston gray, Crimson red etc. in our country (Rabbany et al., 2013). The seed of watermelon is considered as highly nutritious. It is an excellent source of fat, protein, minerals such as $\mathrm{Mg}, \mathrm{K}, \mathrm{P}, \mathrm{Fe}, \mathrm{Zn}, \mathrm{Na}, \mathrm{Ca}, \mathrm{Cu}$, vitamins (A, B) and other phytochemical compounds (Braide et al., 2012). The watermelon seed has an economic advantage. The seeds are ground into flour and used in the preparation of sauces and snacks. The oil obtains from watermelon seed is used in cooking food and manufacture of cosmetics products (Jensen et al., 2011). Watermelon seed is rich in protein; it constitutes nine essential amino acids along with glutamic acid, lysine and tryptophan. The seed of watermelon contains a low amount of carbohydrates but a high amount of calories. For the athlete, roasted watermelon seed can be a best choice as a supplement. The seed is also a good source of different types of fats like monounsaturated fat, polyunsaturated fat and omega- 6 fatty acid which assist in the retrenchment of high blood pressure. Polyunsaturated fat help in reducing blood cholesterol level and cut down the risk of heart disease and type 2 diabetes. The seeds are very useful to cure illness, restoration of health and improve our memory. Protein-energy malnutrition is one of the leading nutritional health problems among children. So for removing malnutrition and mineral deficiency, it is the best option that increases the use of unconventional seeds and cereals like grains as a good source of protein and minerals (Virginia and Ajit, 2014). Functional properties such as water absorption capacity, oil absorption capacity, emulsion activity, emulsion stability, foam stability, foam capacity, bulk density are the idiosyncratic physiochemical properties that affect the protein content of food products during manufacturing and storage of food. Fruit and fruit seed are excellent natural sources of nutritional elements. These natural elements are plant origins and play a vital role in maintaining human health, especially in the prevention of disease, growth and development of our bodies. In the modern era, the demand for phyto-nutrients which are found in the seed of fruits and vegetables is increasing due to public awareness regarding their health (Naz et al., 2013).

Considering the health and economic benefits of unutilized watermelon seed, present research work was aimed to evaluate the chemical composition and functional 
properties of two varieties of locally grown watermelon seed available in Bangladesh.

\section{MATERIALS AND METHODS}

\section{Sample collection}

Two varieties of watermelon seed such as Crimson red (black color) and Charleston gray (brown color ) were collected from the local seed supplier of Chattogram, Bangladesh. Each type of variety was collected from the same lot of seed supplier.

\section{Processing of watermelon seed}

The collected watermelon seed was taken in a dry and clean steel tray. The dirt, foreign materials, immature seed were removed from the fresh matured seed and thoroughly cleaned. The watermelon seed was placed on a cabinet dryer for drying at $60^{\circ} \mathrm{C}$ for $24 \mathrm{~h}$. Then the dried seed was ground by using an electrical grinder to convert the seeds into powder form. The husk was separated from seed powder. The seed powder was packed in polyethylene bags and stored in a vacuum plastic container.

\section{Determination of proximate composition}

The proximate composition of watermelon seed powder such as moisture, ash, protein, fat, fiber was determined in triplicate by following the AOAC method (AOAC, 2005). The total carbohydrate was estimated by subtracting method (Pearson, 1976). The energy value of the seed was calculated according to the formula as reported earlier (Nile and Khobragade, 2009). All proximate contents were expressed in percentage.

\section{Carbohydrate content}

Carbohydrate was estimated by subtracting the percentage amount of moisture, ash, protein, ash and crude fiber from 100 according to subtracting method. Carbohydrate was calculated by the following formula (Pearson, 1976).

$\%$ Carbohydrate $=100-(\%$ Moisture $+\%$ Ash $+\%$ Protein $+\%$ Fat $+\%$ Crude fiber)

\section{Energy value}

Energy value was calculated by the following formula:

Energy value $(\mathrm{Kcal} / 100 \mathrm{~g})=(4 \times \%$ Carbohydrate $)+(9 \times \%$ Fat $)+(4 \times \%$ Protein $)$

\section{Determination of phytochemical compounds}

Crude alkaloid was determined according to the method as described earlier (Harborne, 1998). Saponin was estimated by following the standard protocol (Obadoni and Ochuko, 2002). 


\section{Crude alkaloids content}

Approximately $2.5 \mathrm{~g}$ of watermelon seed powder was mixed with $100 \mathrm{ml}$ of $10 \%$ acetic acid in ethanol. The mixture was incubated at $25^{\circ} \mathrm{C}$ for $4 \mathrm{~h}$ and then percolated the solution. The filtrate was placed in a hot water bath to thicken it up to one-fourth of the actual amount. Then the concentrated $\mathrm{NH}_{4} \mathrm{OH}$ was added drop by drop for precipitation. The precipitates were collected and rinsed with $\mathrm{NH}_{4} \mathrm{OH}$. Then it was allowed to filtration. Finally, the weight of dried alkaloid was taken and estimated by the following formula.

$\%$ Crude Alkaloid $=\frac{\text { Weight of Crude Alkaloid }}{\text { Weight of sample }} \times 100$

\section{Saponin content}

About $5 \mathrm{~g}$ of watermelon seed powder was added with $50 \mathrm{~mL}$ of $20 \%$ aqueous ethanol. The mixture was placed in a hot water bath for heating at $55^{\circ} \mathrm{C}$ for $4 \mathrm{~h}$ and filtrate the solution. The residual was turning out with $50 \mathrm{ml} 20 \%$ ethanol solution. The concentration of extracts was decreased to about $10 \mathrm{ml}$ by heating on hot water bath at $90^{\circ} \mathrm{C}$. Then it takes into a separating funnel and mixed with $20 \mathrm{ml}$ of diethyl ether and agitated the solution. The hydrous was restored when the ether layer was substituted. The clarification system was resolved by adding $15 \mathrm{ml}$ of n-butanol and washed the $\mathrm{n}$ - butanol extracts were rinsed two times with $10 \mathrm{ml} 5 \% \mathrm{NaCl}$. The residual mixture was placed on a water bath and allowed to dry to obtain a constant weight. Then, the saponin content was estimated as a percentage by using the following formula.

$$
\% \text { Saponin }=\frac{\text { Weight of Saponin }}{\text { Weight of sample }} \times 100
$$

\section{Determination of functional properties}

The water absorption capacity of the watermelon seed powder was determined (Phillips et al., 1988). The oil absorption capacity was evaluated according to the standard method (Sosulski, 1962; Njintang et al., 2001). The emulsion activity and stability were estimated (Naczk et al., 1985). The foam capacity and foam stability were determined by following the standard protocol (Coffmann and Garciaj, 1977).

\section{Water absorption capacity (WAC)}

Approximately $2 \mathrm{~g}$ of seed powder $\left(\mathrm{M}_{0}\right)$ was taken in Sorvall ST 8R centrifuge machine (Thermo Fisher Scientific, Germany) tube and added $20 \mathrm{~mL}$ distilled water and agitated for $30 \mathrm{~min}$. Then the solution was placed on a hot water-bath at $37^{\circ} \mathrm{C}$ for 30 minutes and it was centrifuged at $5000 \mathrm{rpm}$ at 10 minutes. Then the obtained sediment $\left(\mathrm{M}_{2}\right)$ was weighed, and it was allowed to dry at $105^{\circ} \mathrm{C}$ to constant weight $\left(\mathrm{M}_{1}\right)$. The water absorption capacity was estimated by the following formula. 


$$
\% \mathrm{WAC}=\frac{\mathrm{M} 2-\mathrm{M} 1}{\mathrm{M} 1} \times 100
$$

\section{Oil absorption capacity (OAC)}

About $1 \mathrm{~g}$ of sample $\left(\mathrm{M}_{0}\right)$ was mixed with $10 \mathrm{ml}$ of soybean oil and agitated the mixture for $30 \mathrm{~min}$., then centrifuged the mixture for $10 \mathrm{~min}$ at $4500 \mathrm{rpm}$ and taken the weight of obtaining sediment $\left(\mathrm{M}_{1}\right)$. The oil absorption capacity was determined by following formula.

$$
\% \mathrm{OAC}=\frac{\mathrm{M} 1-\mathrm{M} 0}{\mathrm{Mo}} \times 100
$$

\section{Emulsion activity (EA)}

About $3 \mathrm{~g}$ of seed powder was mixed with $25 \mathrm{~mL}$ distilled water and blended for $30 \mathrm{~s}$. Then $50 \mathrm{~mL}$ oil were added to it and allowed for homogenization. Then centrifuged the emulsion at $1500 \mathrm{rpm}$ for 5 minutes and determined the emulsion layer. The emulsion activity was determined by the following formula.

$$
\% \mathrm{EA}=\frac{\text { Height of emulsified layer }}{\text { Height of whole layer in centrifuge tube }} \times 100
$$

\section{Emulsion stability (ES)}

The emulsion stability was determined after heating the emulsion contained in the calibrated centrifuged tube at $85{ }^{\circ} \mathrm{C}$ for 15 minutes in a water-bath, allowed to cool for few minutes and again centrifuged at $1500 \mathrm{rpm}$ for 5 minutes. Emulsion activity was determined by the following formula.

$$
\% \mathrm{ES}=\frac{\text { Height of remaining emulsified layer }}{\text { Original emulsion height }} \times 100
$$

\section{Foam capacity and foam stability (FC and FS)}

Around $5 \mathrm{~g}$ of seed powder sample was taken in a $250 \mathrm{~mL}$ cylinder. The volume of seed powder was recorded, and $100 \mathrm{ml}$ of distilled water was mixed with the sample. Then, the mixture was shaken few minutes to obtain foam and recorded the foam volume and foam stability was estimated by recording the foam capacity at 10,30 and 60 minutes intervals. The foam capacity and stability were evaluated by the following formula.

$$
\begin{gathered}
\% \mathrm{FC}=\frac{\text { Volume after homogenization }- \text { Volume before homogenization }}{\text { Volume before homogenization }} \times 100 \\
\% \mathrm{FS}=\frac{\text { Volume after time }(\mathrm{t})}{\text { Initial foam volume }} \times 100
\end{gathered}
$$




\section{Statistical analysis}

All data obtained from the estimation of proximate composition, phytochemical compound and functional properties of watermelon seed powder were imported in Microsoft Excel 2007 spreadsheet for statistical analysis. Statistical data analysis was carried out by using IBM SPSS STATISTICS 25. Data were estimated for statistical significance by using the independent sample ' $t$ ' test for the comparison of mean values, where $n=3$ obtained from the triplicate test for each sample. The statistical data analysis was conducted at a 5\% level of significance. All results were expressed as a mean \pm SD (Standard deviation).

\section{RESULTS AND DISCUSSION}

\section{Proximate composition}

The present research study evaluated the nutritional composition and functional properties of the Crimson red and Charleston gray varieties watermelon seed to attain a scientific basis for the potential use of watermelon seed in the formulation of food products, manufacturing of medicine and industrial purpose. In this study, the moisture content was found for the two varieties of watermelon seed as $3.65 \%$ for Charleston gray and $3.71 \%$ for Crimson red (Table 1). The difference in moisture content between the two varieties was significant $(\mathrm{p}<0.05)$. This result was similar to that of studies reported by Mehra et al. (2015) and Egbuonu (2015). This moisture content was lower than that reported by Akusu and Kiin-Kabari (2015); Tabiri et al. (2016); Hannah and Krishnakumari (2015) and Jacob et al. (2015) who found the moisture content range of 7.1 to $9.59 \%$. The disparity observed in the result might be due to differences in varieties, drying process, and methods of analysis etc. Moisture content is considered an important factor for storage quality of product because high moisture facilitates the rapid growth of microorganism which ultimately spoils the product.

Table 1. Proximate composition of watermelon seed

\begin{tabular}{llll}
\hline \multirow{2}{*}{ Proximate Parameters (\%) } & \multicolumn{2}{c}{ Sample (Watermelon Seed) } & \multirow{2}{*}{ P value } \\
\cline { 2 - 3 } & \multicolumn{1}{c}{ Charleston gray } & Crimson red & \\
\hline Moisture & $3.65 \pm 0.01$ & $3.71 \pm 0.01$ & $>0.05$ \\
Ash & $2.61 \pm 0.01$ & $3.11 \pm 0.01^{* *}$ & $<0.001$ \\
Crude Protein & $22.51 \pm 0.01$ & $27.21 \pm 0.01^{* *}$ & $<0.001$ \\
Crude Fat & $30.65 \pm 0.01$ & $36.61 \pm 0.01^{* *}$ & $<0.001$ \\
Fiber & $29.85 \pm 0.01$ & $21.55 \pm 0.01^{* *}$ & $<0.001$ \\
Carbohydrate & $10.75 \pm 0.01$ & $7.85 \pm 0.01^{* *}$ & $<0.001$ \\
\hline
\end{tabular}

$* * \mathrm{P}<0.01$ 
The ash contents were $2.61 \%$ for Charleston gray and $3.11 \%$ for Crimson red (Table 1). This result showed that the ash content of the seed of Crimson red variety was found higher than the seed of Charleston gray. The result for ash content was consistent with the result reported by Egbuonu (2015); Tabiri et al. (2016); Jacob et al. (2015) and Akusu and Kiin-Kabari (2015) who found the moisture content range of 2.48 to $3.63 \%$ respectively.

The percentage of protein found in this analysis for the two varieties of watermelon seed was $22.51 \%$ for Charleston gray variety and $27.21 \%$ for the Crimson red variety. This analysis revealed that the Crimson red variety of watermelon seed contained a higher amount of protein than that of the Charleston gray variety. The protein percentage found in this study was compatible with that study reported by Akusu and Kiin-Kabari (2015) and Egbuonu (2015) who showed the protein percentage range of 21.46 to $25.33 \%$ and higher than that reported by Tabiri et al. (2016) and Mogotlane et al. (2018) who found the protein content range of 14.90 to $17.75 \%$ and lower than the result $(34.22 \%)$ reported by Mehra et al. (2015). The distinction observed might be due to differences in variety, geographical location, method of analysis, etc.

The fat content of two varieties of watermelon seed was found $30.65 \%$ for the Charleston gray variety and $36.61 \%$ for the Crimson red variety. The result showed that both varieties of watermelon seed contained a high amount of fat or lipid but the fat content of the seed of crimson red variety was higher than Charleston gray variety. This result is consistent with Mogotlane et al. (2018) and Mehra et al. (2015). According to Mogotlane et al. (2018) and Mehra et al. (2015) the range fat content was 31.6 to $34.4 \%$ which was lower than the study result $(45.66 \%)$ reported by Akusu and Kiin-Kabari (2015) and higher than the study result conducted by Tabiri et al. (2016) and Hannah and Krishnakumari (2015).

The fiber and carbohydrate contents were found in this analytical study for two varieties of watermelon seed were $29.85 \%$ of fiber and $10.75 \%$ of carbohydrate for Charleston gray variety and $21.55 \%$ of fiber and $7.85 \%$ of carbohydrate Crimson red variety. This study revealed that the seed of Charleston gray variety contained a higher amount of fiber and carbohydrate than the Crimson red variety. The result found for carbohydrate content is similar to that study reported by Akusu and KiinKabari (2015), higher than that reported by Mogotlane et al. (2018) who showed the carbohydrate content range of 3.16 to $5.26 \%$ and lower than that studies reported by Mehra et al. (2015) and Egbuonu (2015) who revealed a range of 26.57 to $28.07 \%$ of the carbohydrate content in watermelon seed flour. The fiber content obtained in this study was higher than that of analysed by Jacob et al. (2015); Akusu and Kiin-Kabari (2015) and Mehra et al. (2015) who reported a range of 0.1 to $6.4 \%$ of fiber content in watermelon seed.

The energy value found for the two varieties of watermelon seed as $408.85 \pm 0.01$ $\mathrm{Kcal} / 100 \mathrm{~g}$ for the Charleston gray variety and $469.60 \pm 0.01 \mathrm{Kcal} / 100 \mathrm{~g}$ for the 
Crimson red variety (Figure 1). The result showed that the seed of the Crimson red variety contained a higher amount of energy than the seed of the Charleston gray variety. The energy value obtained in the present study was consistent with that study conducted by Hannah and Krishnakumari (2015) who found $465.68 \mathrm{Kcal} / 100 \mathrm{~g}$ for watermelon seed extract, lower than that analytical study reported by Egbuonu (2015); Mehra et al. (2015) who showed that a range of 531.15 to $574.58 \mathrm{kcal} / 100 \mathrm{~g}$ energy value for watermelon seed and higher than the result reported by Tabiri et al. (2016) who found a range of 354.05 to $369.11 \mathrm{Kcal} / 100 \mathrm{~g}$. The disparity observed in the energy value of watermelon seed among the studies might be due to differences in varieties, geographical location, soil, method of analysis etc.

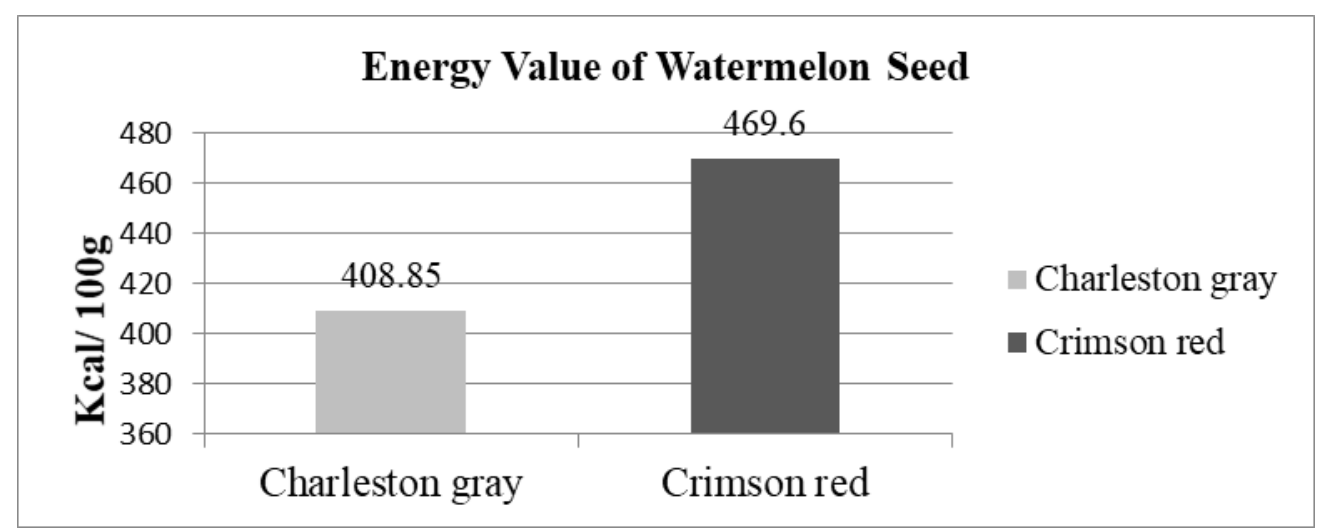

Figure 1. Comparison of energy value between seeds of two watermelon genotypes

\section{Phytochemical compound}

The crude alkaloid content in the seed of Crimson red variety was found higher $(14.05 \pm 0.006 \%)$ than the seed of Charleston gray $(10.56 \pm 0.006 \%)$ (Table 2). The saponin content $(0.04 \%)$ was found the same in two varieties of watermelon seed. The difference in the value of the crude alkaloid content for the two varieties of seed was significant $(p<0.05)$ and the value of saponin content was not significant ( $>>0.05$ ). The result of this study was consistent with that study conducted by Mehra et al. (2015). 
Table 2. Phytochemical compounds of watermelon seeds

\begin{tabular}{cccc}
\hline \multirow{2}{*}{ Phytochemical compound (\%) } & \multicolumn{2}{c}{ Sample (Watermelon Seed) } & \multirow{2}{*}{ P value } \\
\cline { 2 - 3 } & Charleston gray & Crimson red & \\
\hline Crude Alkaloid & $10.56 \pm 0.006$ & $14.05 \pm 0.006^{* *}$ & $<0.001$ \\
Saponin & $0.04 \pm 0.006$ & $0.04 \pm 0.006$ & 1.000 \\
\hline
\end{tabular}

$* * \mathrm{P}<0.05$

Table 3. Functional properties of two watermelon genotypes

\begin{tabular}{cccc}
\hline \multirow{2}{*}{ Functional Parameter $(\%)$} & \multicolumn{2}{c}{ Sample (Watermelon Seed) } & \multirow{2}{*}{ P value } \\
\cline { 2 - 3 } & Charleston gray & Crimson red & \\
\hline Water absorption capacity & $133.33 \pm 0.01$ & $120.33 \pm 0.01^{* *}$ & $<0.001$ \\
Oil absorption capacity & $118.51 \pm 0.01$ & $122.51 \pm 0.01^{* *}$ & $<0.001$ \\
Emulsion activity & $23.31 \pm 0.01$ & $21.41 \pm 0.01^{* *}$ & $<0.001$ \\
Emulsion stability & $11.51 \pm 0.01$ & $11.50 \pm 0.01$ & 1.000 \\
Foam capacity & $4.61 \pm 0.01$ & $6.31 \pm 0.01^{* *}$ & $<0.001$ \\
Foam stability & $45.21 \pm 0.01$ & $39.61 \pm 0.01^{* *}$ & $<0.001$ \\
\hline
\end{tabular}

$* * \mathrm{P}<0.05$

\section{Functional properties}

In the case of the Charleston gray seed the water absorption capacity $(133.33 \pm 0.006$ $\%)$, emulsion activity $(23.31 \pm 0.006 \%)$ and foaming stability $(45.21 \pm .006 \%)$ were found higher than the Crimson red seed (Table 3). On the other hand, the oil absorption capacity $(122.51 \pm 0.006 \%)$ and foam capacity $(6.31 \pm 0.006 \%)$ were higher in Crimson red seed than Charleston gray seed variety (Table 3). The difference in the value of the functional properties for the two varieties of seed, aside emulsion stability was significant $(\mathrm{p}<0.05)$. The functional properties are the intrinsic factors that are important for food processing and storage. The result for functional properties was in contrast to the study reported by Egbuonu (2015) and corresponded to that reported by Marie et al. (2015). The distinction observed might be due to differences in varieties of watermelon, agro-ecological condition, geographical location, climate, propagation method, method of analysis etc. 


\section{CONCLUSION}

The present study evaluated the nutritional, phytochemical and functional properties of two varieties of watermelon seed. The phytochemical compound analysis of the watermelon seed indicated that both varieties of seed contained a good amount of valuable phytochemical compounds such as crude alkaloid. The study result revealed that the two varieties of watermelon seed had good functional characteristics. This research study is an indication that the great potential opportunities for the utilization of the unutilized watermelon seed to develop as medicine, cosmetics, value-added product and dietary supplement instead of throwing them away as waste after consuming the fruit pulp.

\section{CONFLICT OF INTEREST}

The authors have declared no conflict of interest.

\section{ACKNOWLEDGEMENT}

The authors would like to acknowledge the academic staffs of Department of Applied Food Science and Nutrition, Chattogram Veterinary and Animal Sciences University, Khulshi, Chattogram.

\section{REFERENCES}

AOAC. (2005). Official Methods of Analysis. 18th Ed. Association of Official Analytical Chemists. AOAC International. Washington DC, USA.

Akusu, M.O. and Kiin-Kabari, D.B. (2015). Comparative studies on the physicochemical and sensory properties of watermelon (Citrullus lanatus) and melon (Citrullus vulgaris) seed flours used in" EGUSI" soup preparation. Journal of Food Research, 4(5): 1-8.

Braide, W., Odiong, I.J. and Oranusi, S.U. (2012). Phytochemical and antibacterial properties of the seed of watermelon (Citrullus lanatus). Prime Journal of Microbiology Research, 2(3): 99-104.

Coffmann, C.W. and Garciaj, V.V. (1977). Functional properties and amino acid content of a protein isolate from mung bean flour. International Journal of Food Science and Technology, 12(5): 473-484.

Egbuonu, A.C.C. (2015). Comparative investigation of the proximate and functional properties of watermelon (Citrullus lanatus) rind and seed. Research Journal of Environmental Toxicology, 9(3): 160-167.

Hannah, M.A.C. and Krishnakumari, S. (2015). Analysis of mineral elements, proximate and nutritive value in Citrullus vulgaris Schrad. (watermelon) seed extracts. The Pharma Innovation, 4(8, Part A): 7-11.

Harborne, A.J. (1998). Phytochemical methods a guide to modern techniques of plant analysis. Springer Science and Business Media.

Hoque, M.S., Uddin, M.F. and Islam, M.A. (2015). A market model for watermelon with supply under rational expectations: An empiricals study on Bangladesh. European Scientific Journal, 11(9): 236-248. 
Jacob, A.G., Etong, D.I. and Tijjani, A. (2015). Proximate, mineral and anti-nutritional compositions of melon (Citrullus lanatus) seeds. British Journal of Research, 2(5): 142-151.

Jensen, B.D., Hamattal, M.A., Toure, F.A. and Nantoume, A.D. (2011). Watermelons in the sand of Sahara: cultivation and use of indigenous landraces in the Tombouctou region of Mali. Ethnobotany Research and Applications, 9: 151-162.

Marie, N.N.A., Edmond, D.A., Kone, F.M. and Patrice, K.L. (2015). Functional properties of seed flours from different cultivars of Citrullus lanatus (Cucurbitaceae) cultivated in Cote d'Ivoire. International Journal of Research Studies in Agricultural Sciences, 1(5): 32-48.

Mehra, M., Pasricha, V. and Gupta, R.K. (2015). Estimation of nutritional, phytochemical and antioxidant activity of seeds of musk melon (Cucumis melo) and watermelon (Citrullus lanatus) and nutritional analysis of their respective oils. Journal of Pharmacognosy and Phytochemistry, 3(6): 98-102.

Mogotlane, E.A., Mokwala, P.W. and Mangena, P. (2018). Comparative analysis of the chemical compositions of indigenous watermelon (Citrullus lanatus) seeds from two districts in Limpopo Province, South Africa. African Journal of Biotechnology, 17(32): 1001-1006.

Naczk, M., Diosady, L.L. and Rubin, L.J. (1985). Functional properties of canola meals produced by a two-phase solvent extraction system. Journal of Food Science, 50(6): 1685-1688.

Naz, A., Butt, M.S., Pasha, I. and Nawaz, H. (2013). Antioxidant indices of watermelon juice and lycopene extract. Pakistan Journal of Nutrition, 12(3): 255-260.

Nile, S.H. and Khobragade, C.N.N. (2009). Determination of nutritive value and mineral elements of some important medicinal plants from western part of India. Journal of Medicinal Plants, 8(5): 79-88.

Njintang, N.Y., Mbofung, C.M.F. and Waldron, K.W. (2001). In vitro protein digestibility and physicochemical properties of dry red bean (Phaseolus vulgaris) flour: effect of processing and incorporation of soybean and cowpea flour. Journal of Agricultural and Food Chemistry, 49(5): 2465-2471.

Obadoni, B.O. and Ochuko, P.O. (2002). Phytochemical studies and comparative efficacy of the crude extracts of some haemostatic plants in Edo and Delta States of Nigeria. Global Journal of Pure and Applied Sciences, 8(2): 203-208.

Pearson, D. (1976). The chemical analysis of food 7th edition. Churchill Livingstons.

Phillips, R.D., Chinnan, M.S., Branch, A.L., Miller, J. and McWatters, K.H. (1988). Effects of pretreatment on functional and nutritional properties of cowpea meal. Journal of Food Science, 53(3): 805-809.

Rabbany, M.G., Rahman, A., Afrin, S., Hoque, F. and Islam, F. (2013). Cost of production of watermelon and profitability at Gopalgonj district in Bangladesh. European Journal of Banking and Finance, 10(2): 102-112.

Sosulski, F.W. (1962). The centrifuge method for determining flour absorption in hard red spring wheats. Cereal Chemistry, 39: 344-350.

Tabiri, B., Agbenorhevi, J.K., Wireko-Manu, F.D. and Ompouma, E.I. (2016). Watermelon seeds as food: Nutrient composition, phytochemicals and antioxidant activity. International Journal of Nutrition and Food Sciences, 5(2): 139-44.

Virginia, P. and Ajit, P. (2014). Development of nutritious snacks by incorporation of amaranth seeds, watermelon seeds and their flour. Indian Journal of Community Health, 26: 93-101. 